\title{
The Dual Foundation of Universal Jurisdiction: Towards a Jurisprudence for the 'Court of Critique'
}

\author{
Itamar Mann ${ }^{*}$
}

\begin{abstract}
This article revisits the case of The State of Israel v Adolph Eichmann and calls for renewed attention to the analysis of universal jurisdiction in this early example of it. Precisely because the Israeli court's notion of universal jurisdiction is foreign to contemporary readers, it provides fresh guidance on a doctrine that has recently gained enormous importance in global politics. The Eichmann Opinion suggests a two-tiered test: among the cases satisfying the traditional conditions for universal jurisdiction, only those cases in which there is a political interest in pressing charges should be selected. As a world court with universal jurisdiction has not been established, universal jurisdiction remains grounded both in a universal vision of humanity and in the violence wielded by particular institutions.
\end{abstract}

In Order that he who punishes may duly punish, he must possess the right to punish, a right deriving from the criminal's crime.

Hugo Grotius, $1625^{1}$

Where law exists a court will rise. Thus, the court of humanity, if it may so be termed, will never adjourn.

Tribunal in Einzatsgrupen case, United States v Otto Ohlendorf et al, $1948^{2}$

* JSD Candidate and Bernstein Fellow for Human Rights, Yale Law School, USA. Thanks to Seyla Benhabib, Mirjan Damška, Paul Kahn, Claudia Medina, Aziz Rana, James Whitman, the participants of the 2010 Yale Law School Graduate Student Symposium, and the participants of the 2010 Cornell Law School InterUniversity Graduate Student Conference for invaluable comments on early drafts of this paper. I would also like to express my gratitude and appreciation to the anonymous reviewers at Transnational Legal Theory for their excellent suggestions regarding the distillation of the argument, and especially to Craig Scott for his enormous contribution to this article. All errors are of course mine alone.

1 Hugo Grotius, The Laws of War and Peace (Kessinger, 2004 [1625]) 403.

2 Quoted in Jer 40/61 State of Israel v Adolph Eichmann [1962], www.nizkor.org/ftp.cgi/people/e/eichmann. adolf/transcripts/Judgment (accessed 23 February 2011). For an excerpted opinion as to the international law issues considered see Covey Oliver, 'The Attorney-General of the Government of Israel v Eichmann' (1963) 56 American Journal of International Law 805, 821 [Eichmann, Oliver excerpts]. 


\section{INTRODUCTION}

Though seldom employed, universal jurisdiction looms large in international world politics, as a central doctrine of international criminal law. ${ }^{3}$ On 10 February 2011, for example, former President of the United States George W Bush cancelled his first visit to Europe after leaving office, for fear of prosecution in Switzerland. ${ }^{4}$ In this article, I will revisit the case of The State of Israel $v$ Adolph Eichmann in order to suggest how the Opinion of the Jerusalem District Court can help us make new sense of the concept of universal jurisdiction. I will argue that the Eichmann first-instance Opinion lays the basis for a two-tiered test that can provide guidance to courts and prosecutors: among the cases satisfying the traditional conditions for universal jurisdiction, they should properly select only those cases in which there is a public interest in pressing charges. This interest should be articulated, and can then be argued and reviewed. ${ }^{5}$

3 Contemporary cases that immediately come to mind include an indictment in Spain against 'The Bush Six', American officials of the previous administration suspected of torture and kidnappings (see Scott Horton, 'The Bush Six to be Indicted' The Daily Beast, 13 April 2009, www.thedailybeast.com/blogs-and-stories/ 2009-04-13/the-bush-six-to-be-indicted (accessed 23 February 2011). Trials against suspected Somali pirates in Kenya also recently applied universal jurisdiction. Though the latter had a lower profile than the Bushera prosecutions, they were arguably very important in world politics, as they were part of international efforts to secure a lucrative trade route through the Red Sea. Recently Kenya ended its cooperation with the EU on this issue, accusing the international community of failing to fulfil its side of the bargain; see 'Kenya Ends Co-operation in Hosting Somali Pirate Trials' BBC News, 1 October 2010, www.bbc.co.uk/news/worldafrica-11454762 (accessed 23 February 2011). Although all of these cases clearly involve complicated power relations, universal jurisdiction invokes a kind of moral fervour in many of its proponents. Because of the abundance of moral and political rhetoric around universal jurisdiction, the doctrine remains controversial among lawyers.

4 See The War and Peace Report, 10 February 2011, www.youtube.com/watch?v=5A5wn-_XIMo\&feature= player_embedded\#at=220 (accessed 25 February 2011).

5 To be clear from the outset, when I use the expression 'universal jurisdiction', I am referring specifically to jurisdiction exercised through a state's legal system, and not to what might be distinguished as the 'international jurisdiction' of an international body. Also, while the focus of discussion in this article is on a court's exercise of jurisdiction over a defendant (thus, to that extent, universal adjudicative jurisdiction), it will become apparent that prescriptive jurisdiction (the power of a state to prescribe law and prohibit certain behaviour) is always fused with the question of adjudicative jurisdiction and also that the conduct of a court is not simply adjudicative but also to be understood as one facet of the enforcement jurisdiction of a state. Beyond the aforesaid intersection of universal prescriptive/adjudicative/enforcement jurisdiction, it will become further apparent that the thesis of this article is that other non-curial aspects of enforcement jurisdiction are relevant to the question of whether a court may or should exercise adjudicative jurisdiction (notably, the variety of extra-curial activities of state actors from investigation to laying of charges to arrest to carrying out of sentences). That said, an early caution is also in order: this article does not focus on the distinct question of the lawfulness of the specific act of extraterritorial enforcement jurisdiction that preceded the court case, namely the abduction and transfer of Eichmann from Argentina to Israel by Israeli state agents. While the abduction is relevant as an indicator of state actors' perception of connection of the state to the alleged criminal, and such connection is relevant to the thesis of this article, the article does not address whether its approach applies beyond adjudicative jurisdiction to extraterritorial arrest contrary to the law of a foreign state. 
Towards the end of the article, I will discuss cases brought in Belgium in respect of the Congo, and in Kenya and the Seychelles with respect to piracy in the waters off Somalia, in order to illustrate the approach that I suggest with regard to universal jurisdiction.

As will become clear, the argument below is not meant either to support or to oppose prosecution under universal jurisdiction in general, or for that matter in such high-profile cases as Bush's. Rather, it is meant as a call for the countries and jurisdictions involved in such prosecution to articulate the political stakes involved in such dramatic adjudications—as well as their philosophical presuppositions-more openly and clearly. The stakes I will discuss below will remain in question as long as it is domestic courts, rather than international courts, that take on universal claims.

Part 1 of the article discusses Eichmann as a precedent for universal jurisdiction. It discusses the standard political theory behind the doctrine of universal jurisdiction ('the court of last resort'), and the ways in which Eichmann is related to this theory. According to the theory, any court (meeting minimal standards of procedural fairness) can adjudicate certain egregious crimes which are offensive to all humans as such. Parts 2 and 3 introduce the rather different political theory developed by Justice Moshe Landau in Eichmann (the 'dual foundation thesis'). In Part 2, one of the 'foundations' is developed under the title 'The Court of Humanity', signifying the universalistic nature of universal jurisdiction. Part 3 introduces the particularistic 'foundation' that unavoidably remains alongside the universal, under the title 'The Court of Violence'. As the philosophical underpinnings of both 'courts' seemingly contradict one another, Part 4 presents a normative argument for a synthesis between the two, which will be labelled 'The Court of Critique'.

\section{THE STANDARD NOTION OF A COURT OF LAST RESORT}

The prospect of states indicting suspects for egregious crimes committed abroad often appears in the rhetoric of the actors involved as a heroic last measure. When domestic law fails to provide remedies, we are told, and international tribunals are of no avail, there remains an empty seat for international justice. According to this account, any state is fit to step up and preside over such cases — which typically involve crimes conceptualised as injurious to the human community as such. The victims of international crimes are, in turn, invited to knock on doors around the world and have their day in any court that will open. ${ }^{6}$ Call it a 'court of last resort'. ${ }^{7}$

6 The emphasis of this view of universal jurisdiction is the prevention of impunity. Thus, Kenneth Roth, executive director of Human Rights Watch, has written that the 'slowly emerging system of international justice has begun to break this pattern of impunity in national courts'. See Kenneth Roth, 'The Case for Universal Jurisdiction' Foreign Affairs (September/October 2001), www.foreignaffairs.com/articles/57245/ kenneth-roth/the-case-for-universal-jurisdiction (accessed 23 February 2011). This idea developed initially 
This idea of a court of last resort presents the received knowledge, or the doxa, on the role of universal jurisdiction, which I would like to question. To name only one example, this idea figured in the Report of the International Commission of Inquiry on Darfur, headed by Antonio Cassese (2005). As the Commission had it, ${ }^{8}$

The principle of universality empowers any State to bring to trial persons accused of international crimes, regardless of the place of commission of the crime or the nationality of the perpetrator or the victim. The principle is justified by the notion that international crimes constitute attacks on the whole international community and infringe on values shared by all members of that community. (emphasis added)

Almost 50 years ago, very similar language was used by Israel's Jerusalem District Court in its Opinion convicting Adolph Eichmann. ${ }^{9}$ But the Jerusalem court did not see itself as a 'court of last resort'. Rather, the court not only thought that there was good reason why it could try the case against Eichmann, but also that it should be the particular court to act (beyond the functional fact of being an available court). In general, this was conceived of as a political link between the act of crime, the defendants, the victims - and its own identity as a tribunal. ${ }^{10}$ For some, this political link has cast doubt on the idea that this was indeed an instance of universal jurisdiction, properly defined; they prefer to understand the case as an instance of passive personality jurisdiction-a term of art referring to states' jurisdiction over crimes committed by foreign nationals abroad against the state's own nationals. The fact is, however, that the victims of Eichmann's crimes were not citizens of the state of Israel. At the time of the crime, Israel had not yet been established; and even if passive personality can be stretched to the time of adjudication, many of Eichmann's victims died, while others who survived did not emigrate to Israel

after World War II, as part of the discussion around the Nuremberg trials. See eg Willard B Cowles, 'Universality of Jurisdiction over War Crimes' (1945) 33 California Law Review 177, 177: '... [t] he general doctrine recently expounded and called "universality of jurisdiction over war crimes", which has the support of the United Nations War Crimes Commission and according to which every independent State has, under International Law, jurisdiction to punish not only pirates but also war criminals in its custody, regardless of the nationality of the victim or of the place where the offence was committed, particularly where, for some reason, the criminal would otherwise go unpunished ...' However, in this early stage universal jurisdiction was most often considered not to be positively permitted, but rather as not prohibited (ibid, 178).

7 Note that Robert Cover uses the phrase 'court of last resort' in passing in a relevant discussion. The meaning he gives to it is, however, very different from the one it takes here. See Robert Cover, 'Violence and the Word' (1986) 95 Yale Law Journal 1601, 1629.

8 UN Security Council, Report of the International Commission of Inquiry on Darfur to the Secretary-General, UN Doc S/2005/60 (25 January 2005), 154, www.un.org/News/dh/sudan/com_inq_darfur.pdf.

9 n 2 above.

10 Following Michel Foucault's neologism, labelling different configurations of power 'governmentalities', we might use the term tribunalities in order to classify varying configurations of power in a court. See Michel Foucault, 'Governmentality' in Graham Burchell, Colin Gordon and Peter Miller (eds), The Foucault Effect: Studies in Governmentality (University of Chicago Press, 1991) 87-104.

11 Human Rights Council, Agenda Item 7, UN Doc A/HRC/12/48 (25 September 2009). 
after the war. Most importantly, according to the Jerusalem court's own self-understanding, universal jurisdiction was precisely the doctrine it had acted upon.

So, I will take its self-understanding seriously. It is this early understanding of universal jurisdiction that can perhaps shed some fresh light on our understanding of it today. Particularly, I think it can suggest an explanation-both descriptive and normative-not only of the right that states have to potentially try universal crimes, but also of the highly selective process states employ before they decide to do so in reality. The doxa defence of universal jurisdiction celebrates the former, but has nothing to say about the latter-the integration of which into a 'dual foundation' understanding of universal jurisdiction is intended to be the contribution of this intervention.

The image of universal jurisdiction as a 'last resort' appeared, even more recently than the Cassese Darfur report, in the Report of the UN Fact-Finding Mission on the Gaza Conflict ('Goldstone Report', 2009). ${ }^{11}$ Here too the 'principle of universality' is regarded as binding law, reflecting 'fundamental human values', which are therefore 'a concern for the entire international community'. ${ }^{12}$ But even if these crimes concern all humans, both reports ignore the fact that states having universal jurisdiction 'on the books' is a far cry from their determination to actually press charges. In a world where universal jurisdiction is both rarely and selectively applied, the gap between the symbolic recognition that a crime has been committed and the ignition of prosecutorial action demands critical consideration.

The Eichmann trial may have been the first United Nations-era assertion of universal jurisdiction, and perhaps also the boldest one. ${ }^{13}$ Eichmann was tried in Jerusalem in 1961, after he was abducted by Israeli security agents from his domicile in Argentina. In Jerusalem he was convicted of numerous crimes for his part in the extermination of Jews and others by the Nazis during World War II. After his appeal was denied, he was executed in accordance with the penalty handed down by the court of first instance, presided over by Judge Landau. Through a close reading of that first-instance decision by the Jerusalem District Court, I would like to offer an alternative account of universal jurisdiction which I believe explains that employment of universal jurisdiction better than the contemporary notion of a 'court of last resort'.

Hannah Arendt was the most eloquent and influential commentator on the Eichmann trial. Her first-person account of the trial, initially published in parts as a column in The New Yorker, was later collected in the book Eichmann in Jerusalem: A Report on the Banality of Evil. ${ }^{14}$ The book gained a considerable reputation immediately upon its

12 Ibid, 397-8.

13 I have not studied the bases of some other trials in domestic courts after World War II-eg in France for German Crimes against Frenchmen in Germany. They too may have been conceptualised as being based on universal jurisdiction. That said, it may turn out that Eichmann was the first with respect to crimes against humanity.

14 Hannah Arendt, Eichmann in Jerusalem: A Report on the Banality of Evil (Penguin, 2006 [1963]). 
publication, and in recent years has become a classic of 20th century political theory. ${ }^{15} \mathrm{It}$ includes, however, only a sparse reading of the Opinion. ${ }^{16}$ In the same vein, subsequent scholarship addressing the event is considerably richer than commentary on the Opinion. ${ }^{17}$

Arendt has sometimes been understood as supportive of Justice Moshe Landau's stoic effacement of the Israeli prosecution's politicisation of the Eichmann trial. This account of the court's position (whether a correct interpretation of Arendt or not) is not borne out in the Opinion Landau wrote. For Landau, universal jurisdiction-far from Cassese's and Goldstone's ideal-is in important ways an expressive and indeed violent representation of community. The central tenet of his understanding is what is regarded in the Opinion as the dual foundation of universal jurisdiction. What I will therefore call the dual foundation thesis is suggested as the basis for a contemporary version of his view.

The dual foundation thesis offers a framework for openly asserting the political nature of the decision to prosecute in a particular case beyond determination of the existence of formal legal authority (universality of interest) to do so for the kind of crime in question. I will argue, based on my reading of Landau in Eichmann, that a precondition for asserting universal jurisdiction must be the articulation of a political relationship between the tribunal and the defendant. Make no mistake: this is an extremely traditional idea, as we shall see from the historical sources cited by Landau. As contemporary arguments for universal jurisdiction have by and large relegated this idea of a political relationship to obscurity, I will try to explain why and how I think it should be revitalised.

15 For an analysis of the Eichmann trial within the context of Arendt's political theory, see Seyla Benhabib, The Reluctant Modernism of Hannah Arendt (Rowman \& Littlefield, 1996).

16 Arendt (n 14) 244.

17 See eg Shoshana Felman, The Juridical Unconscious: Trials and Traumas in the Twentieth Century (Harvard University Press, 2002) 106-30; Leora Bilsky, Transformative Justice: Israeli Identity on Trial (University of Michigan Press, 2004) 85-165; Gary J Bass, 'The Adolf Eichmann Case: Universal and National Jurisdiction' in Stephen Macedo (ed), Universal Jurisdiction: National Courts and the Prosecution of Serious Crimes under International Law (University of Pennsylvania Press, 2004) 77. The shift of attention from the outcome to the process of the trial seems to be a common feature of trials under international criminal law: see David Luban, 'Fairness to Rightness: Jurisdiction, Legality and the Legitimacy of International Criminal Law' in Samantha Besson and John Tasioulas (eds), The Philosophy of International Law (Oxford University Press, 2010) 575. This line of thought has been so absolutely determinative that today we speak naturally of 'the Eichmann trial' or 'the Eichmann affair', but almost never talk about the case 'like lawyers', as in, 'The State of Israel v Adolph Eichmann', or simply the abbreviated 'Eichmann'. Although one does read or hear 'the Eichmann case', it is usually used in the sense of the overall 'affair' and very often only to refer to the abduction and possibly the specific legal issue of whether a domestic court may retain jurisdiction when a person's appearing before it is due to an illegal capture in a foreign state. Thus it is that appropriating the name of the defendant to signify a legal precedent, versus some 'affair', is almost never uttered. Much work is needed in order to explain what it is in this name that did not allow for such a transposition; or rather, what it is in this trial—or the way it was thought—-that was not amenable to a usual subordination of the event to the textual outcome, although the abduction element would seem to go some way to explaining this and perhaps even the creation of Eichmann as narrative through Arendt's having made the overall case so famous. This essay is an attempt to discover the text buried under the overwhelmingly spectacular event. 
An apparent departure from strictly legal understandings of the reasons for asserting universal jurisdiction may seemingly undermine the most basic assumptions of international criminal law. In other words, it may seem to give way to 'victor's justice'. On the contrary, an openly political choice to prosecute invites reflection on what would be acceptable and unacceptable political rationales; it endorses a consideration not only of the allegations against the suspect, but also of the violent state practices that 'bringing someone to justice' is conditioned upon; ${ }^{18}$ thus, it potentially facilitates vocabularies for global engagement and dialogue.

Victor's justice implies an automatic movement from might to right. Often, the violence of such a movement is later to be denied and practically erased from discussion in the public sphere. Articulating the political relationship between the court and the defendant, on the other hand, is an invitation to reflect, time and time again, on the limits and possibilities that lie in inextricable links between violence, community and identity.

Thus far, all of this may indeed seem quite abstract. I will concretise what I mean as we proceed. Let me first make one more conceptual distinction, which will underpin what follows.

There is a sense in which the 'dual foundation thesis' does take a step towards victor's justice. ${ }^{19}$ As we will see in the Eichmann decision, this can be understood as a demand that universal jurisdiction will be tied up with two types of violence. One can be called constitutive violence. This is the violence that was involved in the very constitution of a state, and hence also of a court (as an organ of the state). This violence of founding a legal order is not conceived a priori as wrong or right, good or bad. It is simply there, behind what we call 'justice'. ${ }^{20}$ The other is what can be called constituted violence. This is the violence of enforcing the already-existing legal order, most often associated with the omnipresent potential of police violence; but also extending to enforcement of law

18 Indeed, what I am trying to offer is an account of international judgment as a practice that involves domination. This is suggested as an account alternative to two very rich bodies of literature. One, informed by philosophy, considers the justifications of international criminal law as an abstract theoretical issue. The other, informed by a different philosophical tradition, emphasises the performative or spectacular aspects of the show trial. Both strands of literature are relatively uninterested in the ways in which, in the context of international criminal law, judges still 'deal pain and death', as Robert Cover wrote (Cover (n 7) 1609).

19 Shai Lavi compellingly makes the analytical and historical connection between Jewish violence post-World War II, the desire for justice, and the modern European nation-state. Lavi's discussion concentrates on vengeance and revenge. At the same time he explains: '[T] he power to punish became the mark of Jewish power, a notion that would repeat itself several years later, when the Eichmann trial became a sign of Jewish sovereignty.' Shai Lavi, “"The Jews are Coming”: Vengeance and Revenge in Post-Nazi Europe’ (2005) 1 Law, Culture and the Humanities 282, 284-91.

20 This position is the legacy of Benjamin, especially in his 'Critique of Violence', in Walter Benjamin, Reflections: Essays, Aphorisms, Autobiographical Writings, Peter Denetz (ed) (Schocken, 1986 [1978]) 277. See also Jacques Derrida, 'Force of Law: The Mystical Foundation of Authority' (1990) 11 Cardozo Law Review (Mary Quaintance trans) 919; Cover (n 7); Robert Cover, 'Nomos and Narrative' (1983-4) 97 Harvard Law Review 4. For a discussion of universal jurisdiction's 'constitutive' force, which fosters 'imagining a world community', see Adeno Addis, 'Imagining the International Community: The Constitutive Dimension of Universal Jurisdiction' (2009) 31(1) Human Rights Quarterly 129. 
through adjudication, and of course to something as exceptional as the abduction by security services of Eichmann in Argentina. The distinction between the two-between constitutive and constituted violence-was originally made by German-Jewish philosopher Walter Benjamin, who, in a 1921 essay entitled 'Critique of Violence', explained that the two kinds of violence are intimately related.

What is required of a court that employs the 'dual foundation thesis' is the task that figures in Benjamin's title: a critique of violence. For Benjamin, this meant expounding violence's 'relation to law and justice'. ${ }^{21}$ For a court employing universal jurisdiction, naturally starting 'from the other direction' of law and justice, this would mean exposing its relation with violence. Such a task, I think, is precisely the task Landau tackles when he develops the idea of the dual foundation of universal jurisdiction. And such a task is what I think a court should engage in when deciding whether to take on universal jurisdiction today.

Such a court could conceivably employ a number of institutional approaches. One might be that the court would interpret formal universal jurisdiction in a limiting way, possibly through a common-law doctrine (resembling forum non conveniens); another less direct approach would be through a power of review over prosecutorial decisions to press charges (that discretion could be overlain with a reviewable duty not to pursue a case without a justifiable political relationship). While these institutional questions remain important, I believe that answers can vary in terms of their appropriateness in particular legal systems. Rather than deciding between them, below I will develop the principle idea of 'the dual foundation thesis' under a label recalling Benjamin's proposition-the Court of Critique.

Perhaps it overstates matters to say that justice is a continuation of war by other means. But insofar as real-life political and legal institutions are in question, state violence should not simply be disregarded, or even understood only as an intervention from an undefined 'outside'. An assertion of right that is truly free of might is only possible, perhaps, in the realms of fiction or faith. This limitation applies in any court. As we shall see, a particular reminder of this is needed in cases of universal jurisdiction, which cannot, I will argue, rest upon social-contract theories granting the state a monopoly over violence.

There is some controversy as to whether the Eichmann trial can be a precedent for contemporary concepts of universal jurisdiction beyond the view discussed above, that Eichmann stands for a form of passive personality jurisdiction. Garry Bass, for example, notes that 'the capture of Adolf Eichmann in Buenos Aires by Israeli agents in April 1960, and his trial in Jerusalem about a year later, was so spectacularly dramatic that it almost seems wrong to look to it as precedent'. ${ }^{22}$

21 This is the opening proposition of Benjamin's essay 'Critique of Violence', ibid.

22 Bass (n 17) 77. Bass quotes Louis Henkin in this context: 'For the law of jurisdiction ... the Eichmann case may be too extraordinary to serve as precedent. Unpunished Nazi criminals will not long be with us. The 
If, however, the event was outstandingly dramatic, the legal issues have been recurrent. ${ }^{23}$ What is more, in practice the Eichmann decision was for a long time at the centre of discussions on universal jurisdiction. ${ }^{24}$ In that sense, it signifies the birth of a modern doctrine of universal jurisdiction. However, rather than assuming that we know what universal jurisdiction is, I will try to learn that from the Opinion. Thus, I will take it as a point of departure, and seek to understand exactly what the precedent means from within its own logic —in terms of the conception developed by Justice Landau.

At the beginning of the Eichmann Opinion, Justice Landau discusses the issue of jurisdiction, presenting the 'dual foundation thesis' for the first time. The court asserts that jurisdiction over Eichmann's case flows both from a universalistic, general grounding in human values and from the particular history of Jewish victimisation. Importantly, Landau understands both as principles of international law. As demonstrated by the quotations from the Darfur and Gaza reports, only the former remains with us in contemporary understandings of universal jurisdiction.

How is it, then, that only one element of this foundational conjunction survived, with particular historical or community connections dropping out of the picture? In order to answer these questions, it might be useful to begin by asking what logical relations are constructed in the Opinion between the two 'foundations' of jurisdiction. ${ }^{25}$ At the outset, the court bases its jurisdiction on an Israeli statute specifically intended to endow Israeli courts with jurisdiction over Nazis and their conduct. The Nazi and Nazi Collaborators (Punishment) Law was enacted in 1950, two years after the state's founding, and five years after the end of World War II. ${ }^{26}$ The statute defines several crimes, asserts Israel's jurisdiction over Nazi suspects, and cancels bars on prosecution due to the rule against retroactivity and limitation periods otherwise applicable to regular crimes.

Perhaps because it circumvents some basic rules of criminal law (territorial application, limitations and non-retroactivity), the statute is not perceived by the court as providing sufficient grounds for prosecution and conviction. Rather than simply

possibility of new genocides cannot, alas, be totally discounted; but it is far from clear that their perpetrators will be brought to judicial trial, and the coincidence of factors impelling exercise of jurisdiction solely on the "universal" principle would in any event be rare ... The Eichmann case reminds us of an area of the law that has not yet been shaken by the new winds.'

23 Thus, prosecutors at the International Criminal Tribunal for the Former Yugoslavia (ICTY) returned to Israeli arguments on the legality of abducting Eichmann from Argentina. Ibid, 78.

24 Luc Reydams, Universal Jurisdiction: International and Municipal Legal Perspectives (Oxford University Press, 2003) 158; Mitsue Inazumi, Universal Jurisdiction in Modern International Law: Expansion of National Jurisdiction for Prosecuting Serious Crimes under International Law (Intersentia, 2005) 63.

25 Notice the close proximity of the current discussion and the fundamental question of Israeli constitutional law: the requirement for a Jewish and Democratic state. As I will emphasise, in the Eichmann Opinion the conjunction is conceptualised as one of international law. For that reason, I intentionally distance the discussion from the seemingly similar one in constitutional law. For more on the constitutional issue, see eg Bilsky (n 17).

26 Nazis and Nazi Collaborators, Punishment Law, 1950, 57 Sefer Ha-Chukkim 281 (Isr) (henceforth: 'The Nazis Act'). 
relying on it, the court proceeds to an exegesis of the historical and philosophical bases of each one of the two 'foundations'. Lacking a written constitution, the court does not have a foundational document to turn to as a juridical source of political values above and beyond legislation. The discussion it engages in, however, has the unmistakable flavour of a constitutional legal theory discussion, articulating what Israel stands for - in the first person plural. ${ }^{27}$

Drawing on both British and Israeli precedent, the court begins with a discussion of the application of international law in Israeli law. Where Israel's international obligations are customary (versus only being found in treaty obligations), as a general rule international law is part of Israeli law in the sense of being directly applicable within the Israeli legal system by the courts. Obligations specific to treaties to which Israel is bound need to be recognised in Israel's legislation before being directly applicable by the courts. However, a principle of interpretation creates a degree of synergy between treaty law and domestic law: whatever the source of international obligations, but especially for obligations that are found only in treaties and not in custom, an Israeli statute must be read so as to agree with the rules of international law, ' $[\mathrm{u}]$ nless its tenor requires another interpretation'. This suggests that Israeli law could be upheld contrary to international law, and indeed this is the normal approach of Israeli courts to this day (where a statute is in conflict with a treaty, notwithstanding efforts to interpret it as favourably as possible to the treaty obligations). ${ }^{28}$ The court explains this immediately before presenting, for the first time, the dual nature of universal jurisdiction: ${ }^{29}$

Our jurisdiction to try this case is based on the Nazis and Nazi Collaborators (Punishment) Law, a statutory law the provisions of which are unequivocal. The court has to give effect to the law of the Knesset, and we cannot entertain the contention that this law conflicts with the principles of international law. For this reason alone, Counsel's first contention must be rejected.

But we have also perused the sources of international law, including the numerous authorities mentioned by learned Counsel in his comprehensive written brief upon which he based his oral pleadings, and by the learned Attorney General in his comprehensive oral pleadings, and have failed to find any foundation for the contention that Israeli law is in conflict with the principles of international law. On the contrary, we have reached the conclusion that the Law in question conforms to the best traditions of the law of nations.

27 See Bilsky (n 17). As many authors have shown, it is true that the link between the constitution of the state of Israel and the trial was starker when it was mouthed by political actors, such as Prime Minister David Ben Gurion. As he said, 'For the first time Israel is judging the murderers of the Jewish people ... And let us bear in mind that only the independence of Israel could create the necessary conditions for this historic act of justice' (emphasis added). See Bass (n 17) 84.

28 However, in the Eichmann case, the court refuses to contemplate recourse to a statutory supremacy rule by refusing to contemplate that international law and the statute could conflict before then determining they do not actually conflict (expressed in terms of unthinkability-some sort of implied faith that the Knesset would never knowingly legislate contrary to international law and possibly also as faith that international law could never actually prohibit the kind of statute here in question).

29 Eichmann, Oliver excerpts (n 2) 808. 
The power of the State of Israel to enact the Law in question or Israel's 'right to punish' is based, with respect to the offences in question, from the point of view of international law, on a dual foundation: The universal character of the crimes in question and their specific character as being designed to exterminate the Jewish People. In what follows, we shall deal with each of these two aspects separately. (emphasis added)

These paragraphs function as a watershed in the argument. From here on, references to jurisdiction flow in two parallel lines, which do not, at least on the face of it, intersect. The legislature's enactment of the Nazis Act, seemingly a good candidate for expressing the new nation's sovereignty, is more or less set aside as the court's normative focal point. More important from this point on are two theories of jurisdiction under international law; two different answers to the question of how Israel, constituted far from the crimes and after they have been perpetrated, gains the authority to prosecute, adjudicate and punish (including, implicitly, the international legal authority to adopt and implement the Nazis Act).

But before we follow the Opinion in separating out these two 'foundations', it is worthwhile emphasising once again that, for Justice Landau, both jurisdiction of 'universal character' and jurisdiction of 'specific character' are validated by international law. Indeed, the first part of the excerpt above makes reference to the authority of the Knesset, the Israeli parliament. But reading on, it quickly becomes clear that the court understands the legal issue at hand as an issue of duality within international law. This judicial focus on duality within international law is not to be taken for granted as a logical orientation for an Israeli court. A seemingly much more obvious discussion would have been a discussion of a dual foundation of the court's jurisdiction in terms of Israeli law (as the foundation of the particular) and international law (as the foundation of the universal). ${ }^{30}$

What does it mean for international law to reflect two different reasonings, which may be thought of as contradictory? And what does it mean to judge a criminal case applying them together? The Jerusalem District Court says almost nothing to clarify. For the court, the two 'foundations' of universal jurisdiction are simply 'cumulative'. ${ }^{31}$ Each of the grounds for jurisdiction is thought of as support for the other, ostensibly weighing the scale further towards the decision to prosecute.

In the following parts of this essay I will try to distill the philosophical presuppositions of each 'foundation' and of their interrelationship. As we shall see, each one of the

30 Indeed, Gary Bass has mistakenly read into the decision a dichotomy between national and universal sources of law. This reading, however, contradicts that text of the decision, which expressly discusses the two components as international. In his reading of the Israeli Supreme Court decision in the appeal, however, Bass does acknowledge a more nuanced relationship between 'the universal' and 'the national'. There, he suggests that Justice Agranat of the Supreme Court aimed to conflate the two categories, perhaps because of his international background as an American. This, however, misses the nuanced reasoning that Justice Landau of the District Court had crafted, which Agranat simply echoes.

31 Eichmann, Oliver excerpts (n 2) 828. 
foundations is based on completely different assumptions about the nature of history, law and politics. I will differentiate the two foundations by thinking of them as two different ideal-types of internationalised adjudication by national courts. As already noted, one of them, the Court of Humanity, has taken prominence in contemporary discussions; its logic has tended to be expressed in terms of a court of last resort (as we have seen with the Cassese/Darfur and Goldstone/Gaza reports). The other, which I will label the Court of Violence, has vanished behind the horizon of the international public sphere but, I will argue, merits resurrection within a synthesis that I will call the Court of Critique.

\section{THE COURT OF HUMANITY}

Although the court refers to the Nazis Act, which allows for jurisdiction over Nazi criminals, it does not expressly rely on the law for its jurisdiction. Rather, the Nazi atrocities give rise to universal jurisdiction as breaches of international law, 'offending human conscience'. ${ }^{32}$ The central operation of the Court of Humanity is therefore moving from Israeli law (the Nazis Act) to international law and human conscience; from positive law to a normative discussion that is not in any way strictly separable from moral judgement. ${ }^{33}$ Essentially, the latter is thought of as the grounding for the decision, which lends normative force to all of the other legal instruments.

Under the logic of the Court of Humanity, the applicable (international and universal) law is recognisable: what it lacks is merely a tribunal. Just like the contemporary Cassese and Goldstone, the Jerusalem court explains that, 'in the absence of an international court', any other country could have judged Eichmann..$^{34}$ But this proposition is not simply given as an axiom (like it is in the two reports). In a remarkably ambitious expedition into what he thinks are the historical sources of the relevant doctrine, Landau reaches back to a pre-national Europe. Addressing issues of jurisdiction in Middle-Age Italy, he cites the trials of wanted fugitives in neighbouring states. ${ }^{35}$ From there on, the Opinion proceeds chronologically and quickly reaches a discussion of Grotius, ${ }^{36}$ a figure

32 Note that the court does not restrict itself in this discussion to the more limited (and available at the time) category of 'crimes against humanity'. The discussion is of penal injunctions under international law at large.

33 Other countries have codified prohibitions on genocide, crimes against humanity and war crimes under their own legislation, without such marks of identity and history. Canada has a specific statute on crimes against humanity and war crimes, and many states that have no connection to genocide in their own national histories have anti-genocide statutes. Iraq executed Saddam Hussein for crimes against humanity under its own criminal code. See Luban (n 17) 572.

34 Eichmann, Oliver excerpts (n 2) 808.

35 Ibid.

36 Ibid, 809. 
who will prove surprisingly prominent throughout the discussion. Quoting from Grotius's On the Rights of War and Peace, Justice Landau reiterates the idea behind this first foundation of universal jurisdiction. Here the court is taking on universal jurisdiction in a way that Landau will himself call, later in the Opinion, 'the court of humanity'. ${ }^{37}$

It is therefore the moral duty of every sovereign state (of 'kings and any who have rights equal to the rights of kings') to enforce the natural right to punish, possessed by the victims of the crime whoever they may be, against criminals whose acts have 'violated in extreme form the law of nature or the law of nations.' By these pronouncements the father of international law laid the foundations for the future definition of the 'crime against humanity' as a 'crime under the law of nations' and to universal jurisdiction over such crimes.

Following this line of reasoning, in trying Eichmann, Israel is in a position every country could be in: it is merely incidental that the Jerusalem District Court was the one to fill the judicial vacuum. ${ }^{38}$ The court is conceived of as an empty, one-size-fits-all judicial robe and chair of honour. Any state may in turn take its place, waiting for a potential suspect to come into view; at which point it can delegate a branch of its own law enforcement, within its territorial borders or without (eg to Argentina), and bring the suspect to justice. $^{39}$

The court considers the question of whether the prosecution of Eichmann is a retroactive application of criminal law. It rejects this contention, asserting that the Nazis Act simply codifies pre-existing customary international law. Thus, 'the crimes dealt with in this case are not crimes under Israeli law alone, but are in essence offences against the law of nations'.$^{40}$ Correspondingly, the criminalisation of genocide is not seen as a fully sovereign act of the parliament of Israel: 'Indeed, the crimes in question are not a free creation of the legislator who enacted the Nazis Act, but have been stated and defined in that law according to a precise pattern of international laws and conventions which set forth crimes under the law of nations.' Here, the image is of a national legal order that is not the origin of its own formal law, but, rather, in some sense a medium for enforcement of what international law has already prescribed (and proscribed). Returning to an earlierintroduced distinction, the Israeli law according to which Eichmann is tried is constituted rather than constitutive.

37 Landau takes this label from a judgment given in the Nuremberg trials, ibid, 821.

38 David Luban expressed this idea that any national court meeting the requirements of natural justice can fill such a judicial vacuum, labelling it judicial eclecticism. See David Luban, 'A Theory of Crimes Against Humanity' (2004) 29 Yale Journal of International Law 85.

39 That said, and as noted in the introduction, this notion of sending forces of order beyond one's own boundaries assumes a lawful assumption of jurisdiction over the person according to international law (eg rules on arrest on the high seas) and/or the law of another state-eg that state's consent to arrest, use of extradition mechanisms, and so on. The 'court of last resort' notion cannot-without more work (not found in this article) - justify the pre-adjudicative seizure of a suspect against the laws of another country.

40 Eichmann, Oliver excerpts (n 2) 812. 
Indeed, as the court discusses retroactivity, the sovereign act of legislation by the Israeli parliament is slighted considerably. ${ }^{41}$ This reduction in legislative power is in tension with political theories of social contract, which would emphasise the ways in which new polities begin new legal orders. Perhaps even more importantly, this assertion is in some tension with the plain meaning of the statutory text. The text distinguishes, in the very first clause, between 'crimes against the Jewish people' and 'crimes against humanity'. ${ }^{42}$ The court, on the other hand, obliterates this distinction. The different terminology in the statute suggests that 'crimes against humanity' internalises a preconceived notion in the international sphere. 'Crimes against the Jewish people' would, conversely, be an independent creation of the newborn polity (and at least partly a reflection of its constitutional makeup). But the court rejects any such reading; it resists attributing any original authority to the Israeli statute, in terms of the criminalisation of Eichmann's acts. Going through Eichmann's indictment, it reduces each charge to a parallel clause in international legal instruments or custom. A statute that textually refers to Jews is rendered identity-blind (whether religious, cultural, ethnic, or in terms of any other relevant identity indicator). ${ }^{43}$

The main legal instrument at hand was the Genocide Convention. Justice Landau approaches the convention through a discussion of the Nazis Act, and shows that the two coincide. First, he quotes section $1(\mathrm{~b})$ of the Nazis Act, which provides: ${ }^{44}$

'Crimes against the Jewish People' means any of the following acts, committed with intent to destroy the Jewish People in whole or in part: (1) killing Jews; (2) causing serious bodily or mental harm to Jews; (3) placing Jews in living conditions calculated to bring about their physical destruction; (4) devising measures intended to prevent births among Jews.

Immediately thereafter, the Opinion introduces the parallel section of the Genocide Convention: ${ }^{45}$

41 The rule against retroactivity in criminal law ('the principle of legality') poses recurring questions about international criminal law. See eg Luban (n 17) 582; Alison Danner and Jenny Martinez, 'Guilty Associations: Joint Criminal Enterprise, Command Responsibility, and the Development of International Criminal Law' (2005) 93 California Law Review 75, 85; Larry May, Crimes Against Humanity: A Normative Account (Cambridge University Press, 2005) 109.

42 See Bass (n 17) 79.

43 Eichmann, Oliver excerpts (n 2) 812. Note, by the way, that the instruments the court refers to can hardly be conceived as sources with the same kind of normative force. The Convention against Genocide, to which Israel was a party, is listed alongside a statute from occupied Germany. Whereas it is obvious why the Convention would apply, the relevance of the German statute to Israeli law is left unexplained. See also ibid, 819.

44 Nazis Act (n 26).

45 Convention on the Prevention and Punishment of the Crime of Genocide, Art 2, 9 December 1948, 1021 UNTS 277. 
In the present Convention genocide means any of the following acts committed with intent to destroy, in whole or in part, a national, ethnic or religious group as such: (a) killing members of the group; (b) causing serious bodily or mental harm to members of the group; (c) deliberately inflicting on the group conditions of life calculated to bring about its physical destruction in whole or in part; (d) imposing measures intended to prevent births within the group; ...

What we see in these sections is indeed an absolute parallel between the Israeli statute and the Convention. The point Landau is making is clear: The court is showing, beyond doubt, that the Nazis Act simply adopted the pre-existing rule regarding genocide. However, the Convention too of course came into being only after the crimes Eichmann was convicted of occurred. Thus, the relationship between the Israeli statute and the Genocide Convention is made more complex by the relationship between the Convention and customary international law.

Just like Israeli law is 'translated' into treaty law, so the treaty (the Genocide Convention) is 'translated' into customary international law. This becomes the crucial point in the court's refutation of the defence's argument that Eichmann's acts were not criminal when carried out. Like the Nazis Act, the relevant instruments in international law are conceived of as articulating pre-existing norms. The court relies on the text of the Convention, as well as that of an International Court of Justice Advisory Opinion, as proof of the prior existence of customary international law norms. Justice Landau quotes the Advisory Opinion: ${ }^{46}$

The origins of the Convention show that it was the intention of the United Nations to condemn and punish genocide as 'a crime under international law' involving a denial of the right of existence of entire human groups, a denial which shocks the conscience of mankind and results in great losses to humanity, and which is contrary to the moral law and to the spirit and aims of the United Nations (Resolution 96(1) of the General Assembly, December 11th, 1946). The first consequence arising from this conception is that the principles underlying the convention are recognized by civilized nations as binding on States, even without any conventional obligation. A second consequence is the universal character of the condemnation 'in order to liberate mankind from such an odious scourge' (preamble to the Convention). The Genocide Convention was therefore intended by the General Assembly and by the contracting parties to be definitely universal in scope. It was in fact approved on December 9th, 1948, by a resolution which was unanimously adopted by fifty-six states.

Landau makes the point about a pre-existing customary norm textually, based on the words 'approve' and 'recognize', when he observes: ${ }^{47}$

46 Reservations to the Convention on the Prevention and Punishment of the Crime of Genocide, 1951 (28 May).

47 Eichmann, Oliver excerpts (n 2) 813. 
The words 'approve' in Article 1 of the convention and 'recognize' in the Advisory Opinion indicate approval and recognition ex tunc, namely the recognition and confirmation that the above-mentioned principles had already been part of customary international law at the time of the perpetration of the shocking crime which led to the United Nations' resolution and the drafting of the convention-crimes of genocide which were perpetrated by the Nazis.

Among other sources, the court cites in persuasive support a Dutch statute which-in view of its language - was thought to allow for retroactive punishment. But when the Dutch court had applied the statute, it declared that 'these provisions have only further defined the jurisdiction as well as the limits of penal liability and the imposition of punishment in respect of acts which already before (their commission) were not permitted by international law and were regarded as crimes' ${ }^{3}$ (emphasis added).

With the Court of Humanity, we encounter norms that are declared to have always/ already been in force. This is ostensibly true of domestic courts transnationally: 'The courts in Germany, too, have rejected the contention that the crimes of the Nazis were not prohibited at the time, and that their perpetrators did not have the requisite criminal intent.' 49

This kind of law is born out of legal practice and history. That said, at the same time the reference to this already-existing customary law is curiously ahistoric in that all that is affirmed is that the norms in question existed prior to the acts being prosecuted, but a foundational moment for the norms is not pinpointed. In this sense, the invocation of custom as pre-existing comes close to a notion of custom within a more natural-law tradition of law that has always existed or that must necessarily exist (which can also be thought of as general principles of law). Such a naturalistic or 'moral law' notion is nearly made explicit both by the International Court of Justice (quoting the General Assembly's Resolution 96) and-as we shall see below—by the Landau court.

The Landau court, however, confronts what seems to be an affirmative bar on its authority within the Genocide Convention, or within the Nazis Act interpreted in light of the Genocide Convention. ${ }^{50}$ Article 6 of the Genocide Convention reads:

Persons charged with genocide or any of the other acts enumerated in article III shall be tried by a competent tribunal of the State in the territory of which the act was committed, or by such international penal tribunal as may have jurisdiction with respect to those Contracting Parties which shall have accepted its jurisdiction.

Territoriality is quite plainly a condition for national-court jurisdiction. The court clearly recognises this problem, alluding to 'territorial jurisdiction as a compulsory minimum'

50 Ibid, 814. Landau writes: 'This conclusion encounters a serious objection in the new light of Article 6 of the convention ...'
} 
within the treaty. ${ }^{51}$ Responding to this difficulty, the court clarifies that acts of genocide occurring before the entry into force of the treaty remain covered by customary international law and that the treaty's procedural and enforcement system does not cover the field for pre-treaty crimes. ${ }^{52}$ According to the Opinion, customary international law refuses to allow for the heinous crime of genocide to be shunted away from the scrutiny of the Court of Humanity. In a short paragraph summarising the way in which both the question of retroactivity and the question of jurisdiction are deduced from customary international law, Landau writes:

This Law [the Nazis Act] does not apply with retroactive effect and does not therefore pertain to the offences dealt with in this case. Our view as to the universality of jurisdiction is not based on this Law or on this interpretation of Article 6 of the Convention, but derives from the basic nature of the crime of genocide as a crime of utmost gravity under international law.

This passage asserts that international custom (with no small hint of naturalistic sources with the reference to 'basic nature of the crime') provides both the court's jurisdiction and the substantive law (of crimes) that the court ends up applying. The Nazis Act seems not so much to be overridden, as sidestepped in favour of another body of law. ${ }^{53}$

Although Landau does refer to the Nazis Act in numerous places in his Opinion, taking the above paragraph seriously means that jurisdiction does not, strictly speaking, rely on the Act at all. In other words, Justice Landau makes it clear that even if the Israeli legislature had not added the Nazis Act to the Israeli law books, his court would have had jurisdiction.

That said, whether or not the Nazis Act is treated as a source of jurisdiction, the bottom line is that Landau turns to custom as essential to the court's jurisdiction over Eichmann. In my opinion, sidestepping the plain language of Article 6 of the Genocide Convention (with its emphasis on adjudicative jurisdiction being based on territoriality of the crimes) in order to interpret customary international law as a full-blown 'law of humanity' remains quite questionable. A different reasoning is needed here, for which Landau himself provides most of the elements elsewhere in his Opinion.

51 Ibid, 818.

$52 \mathrm{Ibid}, 815$ : 'It is clear that article 6, like all other articles which determine the conventional obligations of the contracting parties, is intended for cases of genocide which will occur in future after the ratification of the treaty or adherence thereto by the country or countries concerned. It cannot be assumed, in the absence of an express provision in the convention itself, that any of the conventional obligations, including article 6 , will apply to crimes which had been perpetrated in the past. It is of the essence of conventional obligations, as distinct from the confirmation of existing principles, that unless another intention is implicit, their application shall be ex nunc and not ex tunc.

53 That very sidestepping clearly rejects interpreting the Nazis Act in light of custom (as opposed to only in light of the Genocide Convention). On his own logic, it is not clear why Landau would find it necessary to avoid the Act when the principle of interpreting a statute in light of international law is not limited to using treaties as a reference point for that interpretation but can also include custom as a reference point. Lawful retroactivity could also have been read into the Nazis Act in that manner. 
The leap over a rather clear clause in the Genocide Convention suggests that what the court really does here is not precisely what it says. We can safely assume that, notwithstanding Landau's recourse to what he presents as humanity-affirming custom, such interpretation of Israel's jurisdiction would not have brought the Israeli government of the same era to seek custody of still-living persecutors of the Armenian people in order to bring justice in a court-of-humanity mode. ${ }^{54}$

But beyond what Israeli state authorities would or would not have done in relation to genocides not involving the Jewish people, Landau's own Opinion does not free itself from particularistic rationales for jurisdiction-even as it did find a way to reject pure territoriality as the only form of political relationship that could justify taking jurisdiction. Within the confines of legalism, his method (turning to non-treaty law sources) may have been the best available. However, a philosophically more coherent account of 'custom' would not have simply relied on a court-of-humanity rationale, but would have better integrated the second 'foundation' of universal jurisdiction-described below under 'The Court of Violence'.

A charitable reconstruction of a normative position connecting these two seemingly disparate logics set into the same Opinion-the Court of Humanity and the Court of Violence-will require some reading between the lines, not least because Landau's treatment is very much one of a side-by-side presentation of the two rationales (with, at best, an assumed compatibility between them). That is to follow, under the proposed model for the Court of Critique, for which I will later make a normative argument.

\section{THE COURT OF VIOLENCE}

Founding jurisdiction upon the history of Jewish victimisation, the court unabashedly ties itself to an act of violence. ${ }^{55}$ To be sure, this is explained, problematised violence, but it is unmistakably there. Upon transition from the Court of Humanity, Landau claims a Jewish 'right to punish'. The very sound of this conjunction between right and punishment may seem uncomfortable to the contemporary ear. Punishment by the victim is what one today might call revenge. Yet Landau insists that this right is recognised under international law. ${ }^{56} \mathrm{He}$ presents the right to punish while reiterating the distinction between the two foundations of jurisdiction:

We have discussed at length the international character of the crimes in question because this offers the broadest possible, though not the only, basis for Israel's jurisdiction according to the

54 Here I am referring to what is widely assumed to have been a genocide committed within the Ottoman Empire 1915-17.

55 On the law-making character of violence, see Benjamin (n 20) 283. Also, compare Shai Lavi's discussion of violence in the creation of Jewish identity (n 19).

56 Eichmann, Oliver excerpts (n 2) 828. 
law of nations. No less important from the point of view of international law is the special connection the State of Israel has with such crimes, seeing that the People of Israel (Am Yisrael) - the Jewish People (Ha'am Ha'Yehudi-to use the term in the Israeli legislation) constituted the target and the victim of most of the crimes in question. The State of Israel's 'right to punish' the accused derives, in our view, from two cumulative sources: a universal source (pertaining to the whole of mankind) which vests the right to prosecute and punish crimes of this order in every state within the family of nations; and a specific or national source which gives the victim nation the right to try any who assault its existence.

What are the philosophical and historical assumptions implicit in such a 'right to punish'? One must believe that the victims of the Holocaust had together formed some unitary entity; in other words, that Israel and the victims of the Shoah are in some way the same thing. This is indeed Landau's assumption. It is not, however, an original creation of this judicial opinion.

For one thing, it is influenced by a central assumption of post-war international law documents. The most relevant example is Article 2 of the Genocide Convention, which stresses the cogency of 'national, ethnical, racial or religious' groups. ${ }^{57}$ But even if thinking of a group of people as an entity with some kind of moral cogency is indeed a necessary condition for granting it a 'right to punish', it is not sufficient for justifying such a right. It is a particular kind of group that is required, a kind which is not implied in such legal documents.

Furthermore, assuming that groups have their own moral personality does not entail that the State of Israel is in some way a representative of the Jewish victims of Nazi crimes. In Eichmann, the court goes as far as saying that ' $\mathrm{t}]$ he connection between the State of Israel and the Jewish people needs no explanation'. ${ }^{58}$ It cites the proclamation of the establishment of the State of Israel, which, the court notes, 'makes mention of the very special tragic link between the Nazi crimes, which form the theme of the law in question, and the establishment of the State'. Landau quotes from the Israeli Declaration of Independence: ${ }^{59}$

57 This is one of the most important contributions of Raphael Lemkin, the drafter of the Genocide Convention and its chief advocate in the early years, to international law. As Luban points out, Lemkin cared about national minorities as groups, rather than as collections of individuals. Interestingly, this conception is in some tension with the contemporary understanding of international criminal law as chiefly related to the protection of individual human rights. The latter is the conception of the Court of Humanity. See Luban (n 17) 573-4; Raphael Lemkin, Axis Rule in Occupied Europe (Lawbook Exchange, 1944) 91.

58 Eichmann, Oliver excerpts (n 2) 831.

59 This is perhaps the most important passage in the Opinion, in terms of the way it engages in a discussion about the political meaning of the state of Israel (831). For a useful discussion of the ways in which declarations of independence are always simultaneously declaring the existence of something that has already appeared and bringing something new into existence, see Jacques Derrida, 'Declarations of Independence' (1986) 15 New Political Science 7. For an alternative account of the relations between Jewish statelessness and Jewish political identity see Hannah Arendt, 'We Refugees' (1943) 31 Menorah Journal 69. 
The recent holocaust, which consumed millions of Jews in Europe, provides fresh and unmistakable proof of the necessity of solving the problem of homelessness and lack of independence of the Jewish people by re-establishing the Jewish State which would fling open the gates of the homeland to every Jew and would endow the Jewish people with equality of status within the family of nations ... The remnants of the disastrous slaughter of the Nazis in Europe together with Jews from other lands persisted in making their way to the Land of Israel in defiance of all difficulties, obstacles and dangers. They have not ceased to claim their right to a life of dignity, freedom and honest toil in the ancestral home.

Gary Bass accepts this assumption rather uncritically. As he writes, this is 'the Jewish state trying a man for the extermination of the Jews' ${ }^{60}$ This proposition supports his conclusion that ' $\mathrm{t}$ ] his was a case of distinctly nonuniversal jurisdiction' ${ }^{61}$ But neither the proposition nor the conclusion is as natural as the court (and Bass) would lead us to believe. The former demands a certain worldview of what (a Jewish) nationality might be; the latter is embedded in the contemporary human rights point of view-with its strong idea of universal jurisdiction as 'a court of last resort'.

The story Landau tells is largely a story about how this group entity had survived atrocious hardships, expressed its common identity, and finally came into full existence with Israeli statehood. The court does not invent this narrative; its place is central in the rituals of Israeli citizenship. ${ }^{62}$ The Hegelian language of self-realisation is quite explicit in the court's formulations: ${ }^{63}$ As Landau puts it, the court is writing history 'from object to subject'; ${ }^{64}$ the state is both the agent of salvation and its final proof. ${ }^{65}$

60 Bass (n 17) 78.

61 Ibid.

62 For an influential discussion of the place of the Holocaust in the rituals of Israeli citizenship see Adi Ophir, The Order of Evils: Toward an Ontology of Morals (Zone Books, 2005).

63 I take this to be the central idea in Hegel's theory of law. See GWF Hegel, Hegel's Philosophy of Right (Oxford University Press, 1952).

64 Eichmann, Oliver excerpts (n 2) 834

65 Even if endowing the nation-state with a role of redemption has perhaps more frequently been associated with the political right, note that the reasoning is really indifferent to political partisanship. It has just as often played a role in the conversations of the left. Walter Benjamin attributes to Karl Marx propositions that perfectly express the political sentiment in question, though the object of redemption is not nation but class: 'The subject of historical cognition is the battling, oppressed class itself. In Marx it steps forwards as the final enslaved and avenging class, which carries out the work of the emancipation in the name of generations of downtrodden to its conclusion. This consciousness ... was objectionable to social democracy from the very beginning.' Walter Benjamin, 'Theses on the Philosophy of History' in Walter Benjamin, Illuminations (Schocken, 1968 [1955]) 253. Carl Schmitt has seen such salvation in communism, particularly in the figure of Mao Tse Tung. Political arguments associated with the left-perhaps most eloquently in the writings of Franz Fanon-have used this logic when discussing justifications for violence. As Joseph Slaughter shows, such violence - in the context of anti-colonialism-sets the stage for the appearance of selfdetermination in the vocabulary of international human rights law. Joseph Slaughter, 'A Question of Narration: The Voice in International Human Rights Law' (1997) 19(2) Human Rights Quarterly 406, 412-23. Similarly, labelling the Jerusalem court 'The Court of Violence', when it claims jurisdiction in the name of a battling, oppressed class, is not meant as a criticism of that violence. 'Violence' as I (following Benjamin) mean it here is inherent in any institution that issues punishment. 
But perhaps we have still not said enough. There are non-trivial implications in this political vision, in terms of constitutional theory. On the one hand, writing the history of a nation from object to subject clearly partakes in the project initiated by the Israeli government. The Eichmann trial would then be, in important and conspicuous ways, a display of national identity, or - in other words - a show trial. It is this aspect of the trial that makes Arendt wrathful towards the Jerusalem prosecutor. ${ }^{66}$ Contra Arendt, a reading of the Opinion provides no evidence that the court was opposed to such a project. Quite on the contrary, it appears that the court and the government worked hand in glove in this respect. The to-ing and fro-ing between the court and Gideon Hausner, the prosecutor, as described by Arendt-with Hausner crying in the name of the victims while the court maintains its cool-minded poise-now seems like an orchestrated duo in which the opposing positions actually reinforce and confirm one another.

Somewhat paradoxically, however, the reasoning written into this constitutional moment, to use Bruce Ackerman's term, ${ }^{67}$ has the logical implication of diminishing the importance of the formal enactment of anti-Nazi legislation. This is not to say that it tones down the expression of political community. It simply anchors community before the constitution. Contractarian theories of politics tend to emphasise a radical transformation from a private life in the state of nature to the public life of the state. A constitution or a declaration of independence functions as a contract, a promise, or a speech-act both describing and constituting identity. ${ }^{68}$ In stark contrast, here a communal public sphere is described as prior to statehood, and is unconditioned upon it. In other words, this part of the Opinion favours the nation over the state. The founding actwhether declaration of independence or revolution - is not understood as the stage for a truly new political experience. It is not so much citizenship per se that is sought as a basis for political-legal (indeed, constitutional) commitment to the victims. It is indeed more of a sense of obligation generated by historic community, shared trauma, and belongingness.

This critique may also expose the related disjuncture between what historical time is for the Court of Humanity, and what it is for the Court of Violence. ${ }^{69}$ The understanding of time presented under the first foundation of universal jurisdiction can perhaps be labelled empty time. ${ }^{70}$ It assumes, based on a certain understanding of customary international law, that there is a universal custom, which develops on a worldwide scope. As emphasised above, the law that flows from it feels like a solid rule which is already in place when the court comes to apply it. For the Court of Violence, on the other hand,

66 Arendt (n 14). See also Lavi (n 19) 297.

67 Bruce Ackerman, We the People: Foundations (Harvard University Press, 1991).

68 See Derrida ( $n$ 59).

69 For a related argument on incongruent phenomenologies of time, in a different historical context, see Partha Chatterjee, 'The Nation in Heterogeneous Time' (2005) 37(9) Futures 925; Partha Chatterjee, The Politics of the Governed: Reflections on Popular Politics in Most of the World (Columbia University Press, 2006) 3-26. 70 I draw this terminology from Walter Benjamin's 'Theses on the Philosophy of History' (n 65). 
time is strewn with collectivities that have not yet emerged, and that may potentially emerge, as states. ${ }^{71}$ It is laden with such communities' experiences and hardships. When articulated in the public sphere, and backed up by the possibility of a use of force, time and the experiences of the victims evolve into law. International law is conceptualised as constitutive of the state and its courts in this process.

The court attributes a rather sharp formulation of this proposition to Eugene Aroneanu, a French lawyer. During World War II, Aroneanu fought with the Resistance against the German occupation of France. It was only after the war that he compiled testimonies of the Nazi atrocities. His project was undeniably initiated by the victors, and was carried out in preparation for the Nuremberg tribunals. The court quotes Aroneanu writing in 1948 (the year of Israel's independence) of law 'born in the crematoria-and woe to him who will try to stifle it'. ${ }^{72}$

Justice Simon Agranat of the Israel Supreme Court emphasised the same reasoning on appeal from Landau's first-instance judgment (while refocusing emphasis on the Israeli legislation).${ }^{73} \mathrm{He}$ explained that the Nazis Act ties community to its hardships, prior to political independence:

This law is fundamentally different in its characteristics, in the legal and moral principles underlying it and its spirit, from all other criminal enactments usually found on the Statute books... The penalties included in this law are not intended to right the criminal or to deter potential criminals, but - as the name of the law itself attests - 'to revenge' Israel's enemies and Israel's foes. (emphasis added). ${ }^{74}$

As explained above, the Court of Humanity also underplays the sovereign act of legislation, when it reduces Eichmann's charges to rules of international law. There, Israeli parliamentary legislation was rendered secondary to custom. This invites a comparison of the ways in which sovereignty is bracketed (or indeed, constituted) in each of these ideal-

71 Eichmann, Oliver excerpts (n 2) 832-4. See the discussion of a legal entity dubbed 'a State-on-the-Way'; also, note the fascinating question of what would happen if the Gypsies were to establish their own state on European soil: 'Let us take an extreme example and assume that the Gypsy survivors-an ethnic group or a nation who were also, like the Jewish People, victims of the "crime of genocide" - would have gathered after the War and established a sovereign state in any part of the world. It seems to us that no principle of international law could have denied the new state the natural power to put on trial all those killers of their people who fell into their hands. The right of the injured group to punish offenders derives directly, as Grotius explained ... from the crime committed against them by the offender, and it was only want of sovereignty that denied them the power to try and punish the offender. If the injured group or people thereafter reaches political sovereignty in any territory, it may make use of such sovereignty for the enforcement of its natural right to punish the offender who injured it.'

72 Eichmann, Oliver excerpts (n 2) 821: 'It is not necessary to recapitulate in Jerusalem, fifteen years after Nuremberg, the grounds for the legal rule on the "crime against humanity", for these terms are written in blood, in the torrents of the blood of the Jewish People which was shed. "That law", said Aroneanu in 1948, "was born in the crematoria, and woe to him who will try to stifle it".'

73 In his Opinion, Justice Agranat spoke for the court.

74 Quoted in Lavi (n 19) 297. 
type foundations of universal jurisdiction. ${ }^{75}$ The comparison relates to the ways in which historical time is conceived in both.

In the normative world imagined by the Court of Humanity, customary international law is the source for the enforcement of human dignity when there is no other authority giving the victims voice. When the state implements parliamentary will through legislation, it is simply applying pre-existing international law. The dramatic moment of founding is best understood as internalisation or mirroring of the existing international order. There is supposedly a world-community in which the rule of law pre-exists. Casting this in the terms of contractarian political theory, what we implicitly have is an ongoing worldwide polity. The primordial state of nature in which the rule of law has not yet come into being either vanished long ago, or perhaps never really existed in the first place.

Conversely, where the Court of Violence figures, it is not an act of post-constitution enforcement per se that is imagined, but a violent act of constitution. This constitution is quite perplexing. Politics and indeed international law are understood as an expression of a kind of eternal state of nature (which has its own justice).$^{76}$ The political entity that was victimised reappears in the state, and is not redefined by it.

Furthermore, criminal punishment, under this model, has an extremely close affinity with war. The court finds its intellectual source in a tradition for which war could be just, if it was aimed at punishment. ${ }^{77}$ This intimacy between war and punishment is made possible through a reading of and considerable reliance on the legal-political world envisioned by Grotius. ${ }^{78}$ Indeed, Landau anchors 'the right to punish' in Of the Rights of War and Peace. Natural justice, he explains, gives this right to the victim. Organised society, however, has delegated that right to the sovereign state. ${ }^{79}$ The interesting

75 In both cases, sovereignty is conceived as part and parcel of international law. Landau frames this succinctly: 'In the light of the right of the Jewish people to establish their State, and in the light of the recognition of the established Jewish State by the family of nations, the connection between the Jewish people and the State of Israel constitutes an integral part of the law of nations ...' Eichmann, Oliver excerpts (n 2) 832.

76 Walter Benjamin's reflections on the links between nature and violence are relevant here. See Benjamin (n 20) 278.

77 This tradition is indeed found in Grotius, who writes: 'The justifiable causes generally assigned for war are three, defence, indemnity, and punishment.' See Grotius (n 1) 51.

78 Note also Landau's explanation: 'Grotius holds that the very commission of the crime creates a legal connection between the offender and the victim, and one that vests in the victim the right to punish the offender or demand his punishment. According to natural justice the victim may himself punish the offender, but the organization of society has delegated that natural right to the sovereign State. One of the main objects of the punishment is - continues the author of "The Law of Peace and War" (Book 2, chapter 20) - to ensure that "the victim shall not in future suffer a similar infliction at the hands of the same person or at the hands of others". Grotius also quotes an ancient authority who said that the punishment is necessary to "defend the honor or the authority of his who was hurt by the offence so that the failure to punish may not cause him degradation".' Eichmann, Oliver excerpts (n 2) 830. See also Grotius (n 1) 169.

79 In a different part of the Opinion, Landau paraphrases Grotius, explaining: 'According to natural justice, the victim may take the law into his hand, and himself punish the criminal, and it is also permissible for an innocent man to inflict punishment upon the criminal; but all such natural rights have been limited and restrained by organized society and have been delegated to the Courts of Law.' As Landau continues to 
persistence of natural justice is suggested by the fact that in this part of the Opinion, the state of Israel is conceived not merely as a delegate of the victim. It is literally imagined as the extension (or the logical sublation) of the victim. ${ }^{80}$

If in this case the victim is taking on the right to punish, we are at the same time implicitly told that it is still natural justice that reigns. The pre-enlightenment idea that international law articulates a state of nature between nations comes into play. This thought is of course not new in the intellectual history of international law. It is, however, in irreducible tension with the ultra-legal international sphere envisioned with the Court of Humanity - and with contemporary understandings of international law.

The following passage spells all of this out. Contrary to the previous translation of Israeli legislation to the propositions of international law, here international law is presented as a potent expression of sovereign will-articulated in Israeli legislation. Notice the movement from the understanding of 'group' existing in the Genocide Convention, to the (inter)national understanding of a group that has its own political will (this concept would be labelled today in international law as 'self-determination'): ${ }^{81}$

Even as the Jewish People constituted the object against which the crime was directed, so it is now the competent subject to place on trial those who assailed its existence. The fact that this People changed after the Holocaust from object to subject, and from the victim of a racial crime to the wielder of authority to punish the criminals, is a great historic right that cannot be dismissed. The State of Israel, the sovereign State of the Jewish People, performs through its legislation the task of carrying into effect the right of the Jewish People to punish the criminals who killed its sons with intent to put an end to the survival of this people. We are convinced that this power conforms to existing principles of the law of nations. (emphasis added)

quote from Grotius, these quotes seem to support not only the idea of a Court of Violence, but also the idea of a Court of Humanity. In direct continuation of the previous passage, Landau continues: 'The learned author here adds the important words (italics ours): "It must also be known that kings and any who have rights equal to the rights of kings may demand that punishment be imposed not only for wrongs committed against them or their subjects but also for all such wrongs as do not specifically concern them, but violate in extreme form, in relation to any persons, the law of nature or the law of nations. For the liberty to serve the welfare of human society by imposing penalties which had at first been, as already stated, in the hands of the individuals, has been exercised since the constitution of states and courts, by those with the supreme authority, not because they dominate others, but because they are subject to no one. For subjection to government has taken this right away from others".' See Eichmann, Oliver excerpts (n 2) 809-10. Notice, however, that the way in which the Jerusalem District Court is using Grotius does not support the contemporary idea of a Court of Humanity, which—as explained at the beginning of this essay_can also be understood as a 'court of last resort'. Inasmuch as Grotius is discussing punishment for international crimes, it is punishment from a position of sovereignty ('King'), using force, and very clearly related to the practices of the use of force. The model Grotius is discussing is a model of enforcement-as Landau comments right away after these passages.

80 Grotius differs from other classical writers in international law, as he believes that punishment is authorised by the state of nature, and is not the result of some social contract. See Grotius (n 1) 175.

81 Eichmann, Oliver excerpts (n 2) 834. 
The court does not rely solely on the rather abstract propositions of political theory presented thus far. As with the Court of Humanity, here too the legal questions at hand are universal jurisdiction, and the retroactivity of the criminal sanction. In contradistinction to the Court of Humanity, the Court of Violence answers the first, but has almost nothing meaningful to say about the second.

Landau relates the history of victimisation and the procedural question of jurisdiction through the 'linking point' doctrine. ${ }^{82}$ This doctrine, he writes, is not a creation of the Israeli court. He quotes in this context the 19th century Belgian jurist Gustave RolinJaequemyns as 'having said in 1874': 'The whole world knows that there must be a line of law between he who punishes, and he who is subject to punishment. ${ }^{33}$ Another jurist, Georg Dahm, presents a relatively simple test in which to frame the question of the legality of universal jurisdiction: Does the person or act in question concern the state where the defendant will potentially be tried, more than it concerns other states ${ }^{84}$ Landau quotes Dahm: ${ }^{85}$

Penal jurisdiction is not a matter for everyone to exercise. There must be a 'linking point', a legal connection that links the punisher with the punished. The State may, insofar as international law does not contain rules contradicting this, punish only persons and acts which concern it more than they concern other States. (emphasis added)

The Court of Violence also has an answer to the question about the possible retroactivity of the Nazis statute. This one is perhaps less convincing than the customary international law answer of the Court of Humanity. Perhaps in a way that is clearer than all of the arguments presented thus far, here the Court of Violence replaces an idea of the rule of law with a vision of the practices of war. This vision is interestingly taken from actual experiences in the battlefield: 86

The Hebrew rule 'No one may be punished unless he was forewarned', which corresponds to the principle of legality according to the Roman rule, hints at the importance of warning that a certain action is prohibited. During the World War Allied governments gave the Nazi criminals recurrent warnings that they would be punished, but these were of no avail.

82 'The first appearance of this doctrine in the opinion is with the words of Charles Cheney Hyde: "In order to justify the criminal prosecution by a State of an alien on account of an act committed and consummated by him in a place outside of its territory ... it needs to be established that there is a close and definite connection between that act and the prosecutor, and on which is commonly acknowledged to excuse the exercise of jurisdiction. There are few situations where the requisite connection is deemed to exist ... The connection is, however, apparent when the act of the individual is one which the law of nations itself renders internationally illegal or regards as one which any member of the international society is free to oppose and thwart."' Eichmann, Oliver excerpts (n 2) 811. See also Charles Cheney Hyde, International Law, Chiefly as Interpreted and Applied by the United States, Vol 2 (Little, Brown, 1947) 804.

83 Eichmann, Oliver excerpts (n 2) 829.

84 Ibid, 829.

85 Georg Dahm, Zur Problematik des Volkerstrafrechts (Kohlhammer Verlag, 1958 [1961]) 28.

86 Eichmann, Oliver excerpts (n 2) 824. 
But it is far from clear that such a warning is what is meant by the ancient idea of criminal law captured by the Roman maxim nullum crimen sine lege. What is at stake is the difference between a formal warning, made public in a legal system, and a mere fact of warning, similar to the precautions that military forces are sometimes obliged to take in order not to harm civilians. For the Court of Violence, these two purposes converge.

\section{THE COURT OF CRITIQUE}

What, then, can Landau's Opinion suggest about how universal jurisdiction can and should be re-imagined today? Reconstructing the Opinion, it might make sense to start out by articulating the logical relations between the two 'foundations'. As I argued, these can be understood as representing two ideal-types of adjudicative jurisdiction, set in one Janus-faced Opinion. But Landau does not merely rely on two different legal arguments; as I argued, these arguments suggest two different accounts of what courts do, grounded in two diverging understandings of politics and law-in their relation with history and identity.

Landau understands these two 'foundations' as 'cumulative': 87 they add up, weighing together toward the decision that indeed the Israeli court has jurisdiction over the case. But the seemingly quantitative arithmetic is hardly convincing: it begs further questions about what is the sufficient 'amount' of each and, more importantly, what conceptual framework ties the two together. Furthermore, one may still ask, would the existence of only one 'foundation' suffice? And is either of them necessary?

But perhaps there is a valid reconstruction of the Opinion, under which the logical relation between the two 'foundations' can be understood productively. I think of this suggestion both as the most charitable reading of the decision, and indeed as the outline for a normative argument defending a certain understanding of universal jurisdiction. My reading of the case is that the two conditions were actually required for universal jurisdiction: one is the existence of a crime with a universal character, and the other is a relevant political relationship between the tribunal and the crime, the defendant or the victim. Whereas the former removes concerns of retroactivity (and thus subject-matter jurisdiction as it overlaps with applicable law), the latter placates apprehensions about the exterritorial nature of universal jurisdiction (over events and persons) in which sovereignty seemingly 'exceeds its limits'.

In other words, both conditions are necessary, with neither alone being sufficient. When the Jerusalem court discusses both foundations, it implicitly suggests a two-tiered test. I think this test can be developed in a way that can be generalisable-illuminating not only the Opinion in the Eichmann case but, more interestingly, the class of cases in which it may be justifiable to apply universal jurisdiction in domestic courts in general.

87 Ibid, 828 
As Landau tells us, not every crime justifies universal jurisdiction. The types of crimes that have that potential are crimes with a peculiar relationship to our sense of history. These are crimes that at a certain historical moment seemingly have always been grounded in forbidden acts. This prohibition comes from custom. But it does not, strictly speaking, require an empirical determination that we must turn to historians or archaeologists for help with. Rather, this test, extrapolated from Landau's decision, appeals - through a phenomenology of social and political life-to a moral intuition or sentiment which is leveraged as relevant to the determination of the existence of a customary law rule understood as positive law.

I would like to understand this idea as related to one that David Luban has suggested regarding crimes against humanity: these are crimes that have the essential feature of destroying political society or, as he puts it following Hannah Arendt, the conditions for mutual co-habitation of people in the world.$^{88}$ While Luban seems to formulate the test as a forward-looking one (something like: 'what would pose a danger to the very possibility of living together in the world?'), the way Landau formulates it is rather backward-looking (something like: 'what are the principles that have allowed humans to live together in the world so far?'). The two formulations do, however, share a 'family resemblance', precisely because they both reflect understandings of the relations between political community and historical time. They both justify a claim that there are universal crimes against humanity that arise ipso facto under international customary law, without a need to rely on a positive source of law (notably a treaty but possibly also custom as understood in the positivistic tradition of requiring an intersection of widespread and representative practice of states, which practice is also carried out with a juridical state of mind that the practice is legally required or permitted).

But even if all this is true, the 'judicial eclecticism' that Luban espouses (and that was briefly referenced earlier) does not follow. For Luban, 'judicial eclecticism' means that any domestic court, in which minimal standards of natural justice are met, can justifiably take on universal jurisdiction and try such crimes. But what his account ignores is that institutions of 'justice' are inherently bound up not only in adjudication, but also in the

88 These ideas are inflected by Hannah Arendt's philosophy. For Arendt, what made the Nazis' crimes an attack on the human condition was that they were 'an attack upon human diversity as such, that is, upon a characteristic of the "human status" without which the very words "mankind" or "humanity" would be devoid of meaning' (Arendt (n 2) 268-9). Michael Ignatieff makes a similar argument: 'What it means to be a human being, what defines the very identity we share as a species, is the fact that we are differentiated by race, religion, ethnicity, and individual difference. These differentiations define our identities both as individuals and as species. No other species differentiates itself in this individualized abundance. A sense of otherness, of distinctness, is the very basis of the consciousness of our individuality, and this consciousness, based in difference, is a constitutive element of what it means to be a human being. To attack any of these differences - to round up women because they are women, Jews because they are Jews, whites because they are whites, blacks because they are blacks, gays because they are gay-is to attack the shared element that makes us what we are as a species.' See Michael Ignatieff, 'Lemkin's World' New Republic, 26 February 2001, 27-28. Both quotations can be found in Addis (n 20). 
administrative decisions and actions which allow courts to operate. This, in a nutshell, is what the second tier of the Court of Violence-which is absent from accounts such as Luban's-reminds us, and allows us to reflect upon.

The most important agencies are the police and prosecutorial institutions. Views imagining universal jurisdiction as a Court of Humanity consistently ignore or underemphasise state violence inherent in policing and prosecution-related administrative procedures. I am thinking of such unavoidable choices as: what suspicions to investigate; how to go about investigation; how to question suspects and witnesses, and perform other actions to collect evidence; when to detain or indeed - as happened with Eichmann-abduct a suspect. These are all pre-adjudicative examples, but an account of universal jurisdiction cannot forget that the claim is not simply to adjudicate and pronounce on guilt, but also to sentence and then expect state authorities to carry out that sentence (whether police, prison authorities, possibly psychiatric facilities, the capitalpunishment apparatus in Eichmann's case, and so on). Accounting for such violent actions cannot simply be an analytical or theoretical task, or rest content with founding jurisdiction on 'human values'; it demands a much more socially embedded consideration of the ways in which indictments and criminal trials come into being in domestic courts (and what potential consequences in terms of punishments to be carried out must be factored into those pre-adjudicative decisions). When it comes to international indictments in domestic courts, which so rarely occur and which are so dispersed across space and time, a robust law-and-society approach to understanding these preadjudicative processes seems difficult to follow. We appear to be left only with textual accounts such as the Eichmann Opinion. That said, the Eichmann Opinion does at least provide an exegesis of the politics that brought one such indictment into being.

What we now know from the Eichmann case is perhaps enough to realise that launching international criminal trials in domestic courts indeed requires the work of something like the Court of Violence. The Opinion exposes a built-in violence from the abduction of Eichmann to the general self-assertion of a people. Violence is present even in the last stage of deciding whether to press charges or not. Further, imagining that international crimes are impartially indicted in domestic courts is not sustainable, especially in systems that require politically attuned actors to decide whether to prosecute or not versus independent prosecutors or investigating magistrates. We must find rational ways to understand, discuss and problematise the ways in which decisions are reached if we are to fully justify the assertion of universal jurisdiction in all its violence, and not only in all its humanity.

It might be useful to remind ourselves here of what Kafka describes so well in his novel The Trial. ${ }^{89}$ In important ways, the decisive event in every trial happens before the trial phase-in criminal cases, behind the closed doors of governmental office buildings.

89 Franz Kafka, The Trial, Breon Mitchell (trans) (Schocken, 1998). 
The inner workings of the state occur in a back-and-forth process between policemen and junior prosecutors, between junior prosecutors and their supervisors. The story that will ultimately be related in the indictment will need to be sanctioned by whoever is responsible for the team producing the indictment. Only when it is completely fleshed out will she be likely to lift the veil from the charges, which ideally by now will be armour-clad. From this point on, it's all an uphill struggle for the defendant, not least because judges and juries themselves probably start from the presumption that the prosecuting authorities have done their homework and weighed the consequences of charging or not charging.

In important ways, the theory and doctrine of this pre-trial phase is different in universal jurisdiction cases from what it is in 'ordinary' domestic criminal procedures. In 'ordinary' cases the state's monopoly on the legitimate use of force means that it is expected to enforce the law. This is often considered its legitimate role, as the state is the fiduciary of the citizens-who granted it its powers through social contract. No such obligation to enforce yet exists on the international level, at least in terms of prosecuting on the basis of universal jurisdiction under general international law. ${ }^{90}$

It seems a stretch to speak even metaphorically of a global social contract rendering a state responsible for the citizenry of the world. ${ }^{91}$ On the domestic level, the ideal is that (barring special considerations of public interest) all crimes will be prosecuted, protecting all citizens equally. While asserting universal jurisdiction, however, it will be necessary to choose a limited number of cases from a plethora of potential crimes committed around the world, that formally attract universal jurisdiction (ie on a Court of Humanity basis). What the Court of Violence tells us is that this difference cannot remain unaccounted for.

This prosecutorial power to choose is extremely dangerous in the minds of some critics of universal jurisdiction. For them, it is conceived as sheer arbitrariness further empowering the strong against the weak. Trials for war crimes, crimes against humanity or genocide can easily become forms of subjugation and political coercion, as citizens of some countries are vulnerable to prosecution but citizens of select powers remain immune. It is impossible to take this into serious consideration from within the framework of the Court of Humanity. The mere fact that sometimes only a limited number of compelling complaints are filed by individuals arguing for international prosecution under universal jurisdiction does not solve the problem: while it may make

90 Recognising that there are indeed treaty regimes that are founded on an inchoate duty to prosecute if a person is on a state's territory and the state decides not to extradite when an extradition request comes from another party. See eg UN Convention Against Torture; UN Convention on Disappearances.

91 Addis thinks of universal jurisdiction as an expression of a cosmopolitan world-community. However, in my opinion his account does not convincingly provide a contractarian basis for such a community. Furthermore, it underplays global disagreements on its use (such as in the Bush case) and the coercive powers involved in it. See Addis (n 20). 
such prosecution technically feasible, it is still not a conceptually compelling reason to choose only such cases.

A possible antidote to the arbitrariness of the result can come from the model of the Court of Violence: an explicit doctrinal requirement to justify what the political reasons are for a certain case to be chosen. Reducing such a choice to a sheer measure of 'gravity' is impossible for a state with no intention of replacing the International Criminal Court. Such an explanation of political reasons must be subject to rational scrutiny, including some form of judicial review. ${ }^{92}$

All this may, rather, simply suggest to some that universal jurisdiction is a flawed idea altogether. This point of view appears to be a quite widespread one. In this respect, Paul Kahn makes a relevant argument. ${ }^{93}$ Just like Luban's support of universal jurisdiction, Kahn's rejection of universal jurisdiction is based on a political understanding of law as a mode of living together. For Kahn, law that is not based on political affiliation-affective connections which people are willing to sacrifice for-is groundless, and indeed is not really law at all. It is precisely a respect for the political nature of jurisdiction, and its role in 'constitutional' iterations in the first person plural, which should limit jurisdiction to the domestic sphere of national sovereignty. Kahn would not argue that crimes against humanity are not crimes. He would simply argue that effective and just judgments of such crimes can only be done from within the relevant community. ${ }^{94}$ Reason, as he reminds us, does not as yet have a tribunal that is independent of power. And it is only sovereignty and citizenship which can wield the kind of power that produces the belongingness that citizens are willing to sacrifice for.

Kahn's argument is clearly relevant. Particularly in point is his emphasis on the power that polities are dependent upon, both for their initial establishment and for their ability to issue effective remedies. It is just that part of the argument in which he moves from sacrifice to an essential link with citizenship that I believe is not precise. The discussion of the dual foundation thesis has already suggested that such a primacy of state over community is neither empirically the case nor analytically necessary. Today, modes of political commitment and affiliation often do not match the formal statuses granted by the state. As an empirical matter, de-nationalised political affiliations may very well entail the use of power (and violence), as they entail readiness to sacrifice (the paradigmatic examples are terrorists and political insurgents, some of which do not even aim at state sovereignty, at least not as we know it).

92 Once again, institutionally this can appear in the form of a court of first instance's power (and duty) to review the exercise of prosecutorial 'discretion' to charge someone now before that court, or in the form of judicial review of that court of first instance's own review of the decision to accept or decline universal jurisdiction.

93 Paul Kahn, 'On Pinochet' Boston Review (February/March 1999), http://bostonreview.net/BR24.1/kahn.html (accessed 27 February 2011).

94 Ibid. 
When a court asserts universal jurisdiction, it should be aware and open about the fact that what is in question is a mode of transnational solidarity, and not simply a technical role of adjudication or an idealistic responsibility for 'humanity'. Such solidarity, as Gary Bass emphasises, demands a price. ${ }^{95}$ Only courts in jurisdictions that are 'willing to pay the price', as it were, are likely to take on universal jurisdiction in concrete cases. Bass notes: ${ }^{96}$

Universal jurisdiction ... means embroiling one's diplomatic apparatus in the imbroglio and, quite likely, a confrontation with one or more states; it means setting a precedent that undermines one's own national sovereignty, it means burdening one's court system with what will probably be an incredibly complex and problematic case; and it almost certainly means a great deal of domestic turmoil and controversy. Why should a country bother? The Eichmann case gives one clear answer: because the country feels itself to have been victimized.

This 'price', which may be regarded as a sacrifice of sorts, is really another way of asserting the importance of the doctrine of 'the linking point' and the role of the Court of Violence. But, contrary to Bass's concluding line above, it does not necessarily involve, as was the case in the Eichmann trial, a relationship between the criminal and the victim. Bass's misconception in this respect results from the fact that he does not fully grasp the experience of historical time that is at work in the ideal-type of the Court of Violence. As explained above, this experience of time is deeply transformative (and constitutive). The identity the court creates with the victims cannot be conceived, as Bass thinks of it, as a pre-existing fact of nature or history, something that was available for perception before the court had pronounced it. In Eichmann, the court partakes in a moment of utmost constitutional significance-reasserting what the state of Israel stands for. The experience of time described under the label of the Court of Violence enables us to think of the moment the collectivity of victims and the community of Israeli citizens consolidated into one-or at least were imagined as having done so. As historian Tom Segev shows, this was far from being true before the Eichmann trial. ${ }^{97}$

There is therefore no reason to think that the particular political relation between victim and perpetrator is the only one that can lead a court to take on universal jurisdiction. Different kinds of political relationships, which are strong enough to make a country 'pay the required price', can be relevant. The critical point is to invite discussion of what kinds of political relationship are indeed the ones that should grant such universal jurisdiction. Practically, this would require the court to openly state in its decision the kind of political engagement that made it take on a case. Such iterations by courts are comparable to those in more traditional constitutional cases, when courts openly make determinations on the character of their own polity.

95 Bass (n 17) 78.

96 Ibid.

97 Tom Segev, The Seventh Million: The Israelis and the Holocaust (Picador, 2000). 
What this means is that there might indeed be cases in which a grave crime of international character occurred, but not all technically capable and logistically available jurisdictions are fit to hear the criminal case that follows. This is not necessarily to say that only one jurisdiction would be suitable; it does however entail that there may be jurisdictions that would be categorically excluded. And as in any field of law, there may be disagreements as to the proper results. The only purpose at present is to show the usefulness of this type of analysis.

The political understanding of jurisdiction in both Kahn and in Luban rejects the exclusively utilitarian assumptions of some proponents and opponents of universal jurisdiction. Like both authors, I too reject the understanding of this judgment as simply utilitarian or instrumental in some wider sense. But even if the relevant transnational solidarity with victims envisioned by Luban does exist, there remains a need to conceptualise the relations between this identity and the actual practices of institutional violence..$^{98}$ Attention should be directed not only to the question whether we can say 'we' on a global scale. It should also focus on the question whether there are enforcement authorities that can carry out tasks in the name of such a solidaristic conception within the context of domestic court systems.

Luban does address the concern with the practices of violence, in the context of an explanation of why a monopoly of states on the violence of international criminal law is important. Thus he emphasises, amongst other things, that international prosecution requires the gathering of evidence from foreign war zones by impartial investigators; the provision of defence counsel; the establishment of safe and humane prisons; and the drafting of rules for all such procedures. His underlying emphasis here is on 'procedural fairness'. ${ }^{99}$ 'Realistically', he concludes, 'only states can carry out these tasks'.

But there is more to this monopoly on violence than the mere fact that states are equipped to handle it. Furthermore, the wide outsourcing of war tasks by the US government, in Iraq and in other places, has proven that it is not at all clear that states are advantaged over private actors in administering politically sanctioned violence. Much will depend on the particular states and private actors in question. Luban assumes that the tasks he lists are carried out in more or less the same way by all states. This is almost certainly not true in terms of the wide disparities of resources, institutional effectiveness and rule-of-law capacities. But it is also not true on the level of basic comparative law: rules of evidence, for example, vary greatly, in ways that, as Mirjan Damaska has shown, reflect different cultures and understandings of justice-and that will certainly be relevant to the justifiability of exercises of universal jurisdiction. ${ }^{100}$

98 See also Cover (n 7) 1611-12.

99 Luban (n 17) 580.

100 Some might respond that rules of evidence are procedural and not substantive, and that defendants do not have rights to be judged under particular rules of procedure. But even if that is true, what we are talking about in the context of universal jurisdiction is changing a full-fledged system for inflicting societal violence. 
What is more important than the efficacy of state violence is the way in which legal structures of violence reflect (or do not reflect) decisions made by communities about how to live together, and with their neighbours. Every cog in the machine of prosecution is presumably bound by rules and institutional traditions, which members of the social contract are supposed to share and have a stake in. ${ }^{101}$ When prosecution steps beyond that contract to the universal level, the violence that was legitimated on the domestic level does not simply disappear; its politics may become groundless or seemingly unrelated to the constitution of identity, unless, once again, such political links are explicitly discussed and chosen as well as persuasively justified. In order to perform such tasks responsibly we must recognise, not deny, that such a decision brings criminal prosecution closer to a war paradigm. In this respect, the Grotian conceptions referred to and developed by Landau in his Opinion may not seem all that dated.

My suggestion may seem curiously circular. It explains when states are likely to take on universal jurisdiction, as a descriptive matter ('when political links exist'); at the same time, it purports to explain when states should take on universal jurisdiction, as a prescriptive matter (and indeed, by the same measure- ' when political links exist'). Note, however, that even though such a political link is required, not all political links are to be accepted as appropriate reasons for international prosecution in a domestic court. The role of the Court of Critique would be to develop judicial mechanisms to criticise and review such reasons. The challenge it aims to pose before a prosecutor is to temporarily pull up the veil of prosecutorial discretion. Technical definition of the desirable mechanisms and indeed the precise principles for performing such a task is outside the scope of the present article. However, let me provide some concrete examples of how the 'dual foundation thesis' may be useful in framing thoughts of universal jurisdiction, and give an idea of the sorts of considerations that I think should be involved in a jurisprudence for the Court of Critique.

In his argument, Luban revisits Justice Bula-Bula's Opinion in Congo v Belgium, ${ }^{102}$ an International Court of Justice case in which Congo appealed to annul an arrest warrant issued by Belgium against Abdoulaye Yerodia Ndombasi, the Foreign Minister of Congo (at the time of the issuing of the warrant). Interestingly, the case deals with a core issue of pre-trial use of state violence. The case was decided against Belgium, and Yerodia's immunity as a state official was upheld. While other Opinions focus on the technicalities of international criminal law, Bula-Bula aims, in his own words, to go beyond 'the visible face of the iceberg' and address the very painful political link between Belgium and Congo - the link that in his opinion was the decisive fact behind the decision to prosecute.

Bula-Bula writes in his Opinion, quite impassionedly, that the warrant against Yerodia was related to and marred by Belgium's post-colonial agendas and enterprises of

101 It must not go unnoticed that the agency that Walter Benjamin thought was most closely bound up with both constituted and constitutive state violence was the police. See Benjamin (n 20). 102 Case Concerning the Arrest Warrant of 11 April 2000 (DRC v Belgium), 2002 (14 February). 
exploitation in Congo. He celebrates the potential that rules of jurisdictional immunity have in creating a level playing field among the states of the world. These formal rules protect the sovereignty of all impartially, and create equality between former colonies and former colonisers. As Luban recounts, known historical facts do not contradict BulaBula's allegations against Belgium. According to Luban, Bula-Bula's Opinion is not so much about formal immunity; it is more about natural justice. Remember that Luban's criterion for universal jurisdiction is that any court observing principles of natural justice may take on jurisdiction in cases of certain heinous crimes. An ongoing legacy of colonial oppression is thus understood as something that can exclude a court from meeting the criterion of observing natural justice in a particular case. And that is so, even if the very same court is in general recognised as one in which natural justice is strictly observed. ${ }^{103}$

I agree with Luban that Bula-Bula's dive deep into the dark waters of colonialism and neo-colonialism to reveal the ominous magnitude of the iceberg under its surface is not reducible to the formal discussion on immunity. However, I am not convinced by Luban's alternative association of this reasoning with the principles of natural justice. The dual foundation thesis provides more accurate analytical tools to comprehend the need BulaBula felt for such an analysis of Belgium's decision to prosecute. His Opinion might thus be read as a protest against the hypocritical way in which Belgium disguises its links to violence in Congo. In Luban the emphasis on justice as fairness precludes this prosecution inasmuch as the information Bula-Bula presents reflects 'base political motives' for prosecution. ${ }^{104}$ However, the present interpretation of Bula-Bula suggests that such prosecution could be precluded, for the very reason that Belgium should not be the country to do so, because of its bloody history there.

For Bula-Bula, this is an example in which the 'political link' is clearly visible, and is one which cannot pass muster. Hence, the 'dual foundation thesis' helps us understand why a given court should not take on universal jurisdiction. Indeed, it is of course made clear by this example that it is not enough simply that a 'political link' exists. Rather, the decisive issue is whether such a link justifies an international prosecution, or rather taints it as in this case. Bula-Bula's Opinion is therefore an example of the sort of examination that is precisely the role of the Court of Critique.

From another perspective, consider the prosecutions by Kenya's and the Seychelles' courts of Somalian pirates on the basis of universal jurisdiction. These courts receive abundant funding from Western countries, which initiated their operation according to their own needs. This response to the developing piracy problem evolved after Western countries decided that they prefer not to indict on their own territories. As reported, these countries were fearful of the possibility that suspected pirates would submit requests for asylum on their territory, thus creating unwanted obligations towards them, and making

103 Luban (n 38) 150.

104 Ibid. 
them difficult to deport. They also did not want the trouble of keeping them in their prisons, and dealing with post-prison sentence deportations. These piracy courts operate in incredibly problematic jurisdictions in that, as Mateo Taussig-Rubbo has shown, ${ }^{105}$ they are otherwise scarcely capable of performing law-enforcement tasks. From the perspective proposed in this paper, are these justified utilisations of universal jurisdiction?

A Court of Critique would demand that the political link between the court's state and the defendant be exposed. Thus, the pirate cases present from our perspective a considerable problem: it seems that this 'outsourcing' is a way of denying and allowing the true interested parties to avoid paying the 'price' of performing international criminal justice. One may of course respond that the interested parties paid the required price quite literally, with compensation to the Kenyans to carry out the task. But such a response is inconsistent with the way I tried to take seriously the public and civic meaning of an open court procedure. Furthermore, as it became clear from Kenyan complaints that the benefactors were not keeping their promises, the tribunals indeed stopped operating and essentially failed.

Consider, however, two hypotheticals: in one, Kenyan prosecutors explain that although granted outside funding for prosecution, the state also has an independent political interest in prosecuting the pirates: they have detrimental effects on Kenya as they block close and essential waterways. This explanation may indeed satisfy a judge that sufficient political links exist between Kenya and this particular case. Alternatively, imagine that later, documents show that Kenya actually decided to prosecute, as the government wanted the money in order to enhance its own judiciary. From the perspective of the Court of Critique this may justify barring the government from moving forward. This is so not only because it becomes clear that the government has misrepresented its political interests; it is also relevant that the true motive for prosecution is not related to the particular defendants, and turns them into means towards ends unrelated to their actions.

We might also recall that in an article arguing against universal jurisdiction, George Fletcher asks what would have been the proper response if Argentina had decided to prosecute Eichmann, preventing the Israeli trial. Fletcher suggests that such a trial would not be acceptable, as Argentina would be suspected of 'insufficient determination to convict'. But use of 'determination to convict' as a measure of legitimacy of willingness to prosecute is conceptually very problematic in a criminal trial, seemingly contradicting the presumption of innocence.

If indeed an Argentinean prosecution would cause discomfort, this could be the result of a lack of commitment not to convict, but rather to conduct a fair trial. This idea is encapsulated in the Rome Statute, which demands that prosecution be genuine, and not

105 Mateo Taussig-Rubbo, 'Pirate Trials, the ICC and Mob Justice: Postcolonial Forms of Sovereignty in Kenya', www.law.yale.edu/documents/pdf/sela/SELA_Taussig_PV_20100712.pdf (accessed 27 February 2011). 
a way of protecting perpetrators from criminal charges (under the double jeopardy principle). Alternatively, the discomfort could perhaps also arise from a presumed lack of political link between Argentina and the case. But if the Argentinean prosecution overtly explained that it had decided to indict Eichmann because he had become part of the Argentinean community, that indeed may be a salient argument. In such a case, Argentineans had presumably developed a special public interest in finding out the truth about their neighbour. Possibly, also, one could imagine reasoning grounded even more closely in political community and identity, if, for instance, the Argentine authorities felt a measure of shame that previous regimes had been harbouring Eichmann.

Ultimately, and taking into account examples such as those discussed above, the contribution of the Court of Violence to the task of the Court of Critique can be formulated in terms of the familiar 'public interest' prosecutorial consideration. Generally in criminal cases there is a presumption that, when there is evidence, a case should be prosecuted. This presumption can be rebutted by 'public interest' to the contrary. With universal jurisdiction, the opposite may be true: In order to issue an indictment, the prosecution must positively convince the court that a 'public interest' exists.

When the Jerusalem District Court decided Eichmann, it did precisely that. Thus, it exposed its political foundation in violence, and took account of that violence's civic role. To the extent that we find the reasoning persuasive (something this article did not consider), it can thus be called a Court of Critique. The Court of Critique label highlights the way in which such a court extends its reach outside the normal order of domestic law, in a certain act of violence. At the same time, the court articulates, problematises and questions the political conditions of power that were required in order to do so. If done to its fullest, such a critique provides a defence of universal jurisdiction.

\section{CONCLUSION}

I have argued for an explicit recognition of the political reasons for international prosecution under universal jurisdiction. According to this account, universal jurisdiction will not only in fact be, but should properly and explicitly be, specific rather than general, partial rather than wholly impartial.

Although it relies on an historical example, this argument is meant as a possible starting point for political debate about international prosecution as one instrument of international engagement in the present. But recognising the political nature of prosecution, and indeed the practices of criminal prosecution (which, as I emphasised, oftentimes happen outside the court), is not a sufficient condition for the Court of Critique. Left on its own, a Court of Critique focused solely on the justifications offered by the Court of Violence will too easily yield to brute force, and to victor's justice. This is why it is important to emphasise the dual foundation of universal jurisdiction: the Court 
of Humanity must always stay in view. A combination of the two foundations is necessary and sufficient for asserting universal jurisdiction. Generally, the Court of Humanity will provide the foundation for the substantive law that applies. The Court of Violence will be involved in actually choosing to use the force required to 'bring someone to justice'.

Finally, we must not forget that the Court of Critique, when it authorises prosecution based on universal jurisdiction, will itself still be engaged in certain violence. But we would do well to recall that such a foundation in violence is not peculiar to cases of universal jurisdiction. Domestic courts too are grounded in violence, in terms of being the outgrowth of (and sometimes the participants in) a violent act of constituting new polities, and in terms of the day-to-day violence of a constituted polity engaged in enforcement of its legal order. But just as domestic courts need to be impartial while maintaining their grounding in a particular community, so too must the Court of Critique hold in some equipose the Court of Humanity and the Court of Violence, if its own legitimcay is not to be put at risk. 